CRISTIAN MOROIANU

\title{
REFLECTĂRI ALE ETIMOLOGIEI MULTIPLE ÎN DA
}

\section{Chestiuni generale}

Etimologia multiplă reprezintă, cel puțin în lingvistica românească modernă și contemporană, proveniența unei unități de limbă (mai ales a unui cuvânt sau a unei unități frazeologice) din două sau mai multe surse directe (interne, externe și mixte), care reprezintă etape diacronice şi diatopice ale pătrunderii și circulaţiei unui singur etimon (indirect sau îndepărtat) și care nu au cunoscut, prin raportare la acesta din urmă, modificări de ordin derivativ. Discuția de față va avea în vedere cel mai important dintre cele trei tipuri pe care le îmbracă acest fenomen lingvistic, anume etimologia multiplă externă de tip lexical.

Rezultatul manifest al etimologiei lexicale multiple externe se reflectă în existența așa-numitelor variante etimologice (fonomorfologice, accentuale, grafice) ale cuvintelor rezultate, care corespund respectării criteriului formal al unei etimologii ştiinţifice.

Etimologia multiplă este o realitate a existenței unei/unor limbi a cărei/căror poziționare geografică și evoluție istorică (socio-politică și culturală) a/au fost influențate (simultan sau succesiv) de mai multe limbi, culturi și civilizații. Printre aceste limbi se află, în mod particular, și româna, constituită și vorbită natural într-un spațiu geografic înconjurat de popoare și de limbi diferite ca origine (nonlatine), dezvoltată mai târziu cultural sub influența unor limbi ca germana, maghiara, neogreaca, rusa, la care se adaugă, începând cu epoca modernă, limbile romanice și latina cultă. Așadar, lexicul și frazeologia românească s-au îmbogăţit prin aportul - atât simultan, cât și succesiv - pe cale populară sau, mai ales, cultă al tuturor acestor limbi, vecine geografic sau înrudite originar, ceea ce a dus la existența în limbă a numeroase variante explicabile în primul rând etimologic.

Fenomenul a fost intuit și valorificat, fără să fie numit însă ca atare, în lucrări lexicografice ca Lexiconul de la Buda (LB 1825), Dicționarul academic latinist al lui A. T. Laurian și I. C. Maxim (LM 1873-1876) sau Dicționarul-tezaur al limbii române (DA 1906-1948), coordonat de Sextil Pușcariu, până să devină un „brand” al lingvisticii românești odată cu lansarea și denumirea lui ca atare de către Alexandru Graur (1950). Începând de atunci, conceptul de etimologie lexicală multiplă externă a fost valorificat, dezvoltat și, în același timp, discutat critic de N. A. Ursu (1962, 1965, 1970, 2004-2011), Al. Niculescu (1960, 1978), Mircea și Luiza Seche (1965), Th. Hristea (1968, 1973, 1978), A. Avram (1968, 1970, 1997), Stelian Dumistrăcel [...], Florica Dimitrescu (1990) și mulți alții ${ }^{1}$.

\footnotetext{
1 Pentru bibliografia problemei, vezi Celac-Moroianu 2018, p. 307-310. Dintre contribuțiile recente, sunt de semnalat, în mod particular, Celac 2017, p. 101-130 și Bogdan-Oprea 2011.
} 
Materialul de față are ca substanță situații de reflectare a etimologiei lexicale multiple externe în DA, vol. I, litera A (cu exemple până la Ar). Fiecare articol citat este urmat de corespondența cu articolul similar din DELR, litera A (ediția revăzută și adăugită, aflată în curs de apariție la Editura Academiei și prezentă online, cu acces liber, la adresa https://delr.solirom.ro).

\section{Etimologia multiplă în DA}

Fără nicio urmă de îndoială, DA este dicționarul nostru istoric de referință, realizat de o echipă de lexicologi și lexicografi care, sub coordonarea lui Sextil Pușcariu, au reușit să construiască o operă de mare substanță prin diversitatea materialului lingvistic valorificat, prin abordarea științifică de mare finețe intelectuală, dar și prin amprenta culturală şi umană a autorilor, oameni de cultură cu o mare știință de carte și cu un devotament particular pentru limba proprie. După mai bine de un secol de la încheierea lui, DA-ul rămâne un model lexicografic spre care ne îndreptăm, mulți dintre noi, cu sfială și admirație.

Deși etimologia multiplă nu era, în epoca realizării lui, un concept lingvistic explicit, autorii DA-ului au intuit, și după opinia noastră, existența realității lui prin formulări care constituie esența comunicării de astăzi. În capitolul „Forma neologismului” (404-407), care aparține părții a VI-a (Influențe culturale) din vol. I Limba română (1940), Sextil Pușcariu discută explicit originea multiplă a împrumuturilor:

„În toate timpurile vedem cum neologismele șovăe între forma franceză, cea etimologică latină și cea adaptată românească. Astfel, alături de fantazie (lat.) se întrebuințează fantezie (franc.) și, dimpotrivă, alături de condemnare (lat. condemnare) - la C. Negruzzi - avem mai des condamnare (franc. condamner). Alături de coloare, novelă etc., care redau vocalismul latinesc (color, -orem, novella), se întrebuințează formele cu vocalism francez: culoare, nuvelă (couleur, nouvelle). [...]. După cum cuvântul este luat din franțuzește, nemț̦ește sau din latinește (unde el e adesea de origine grecească), vedem cum șovăe uzul cu privire la gen și la accent: sistem-sistemă, programprogramă, grup-grupă [...]".

După cum se poate observa, Pușcariu este conștient atât de existența variantelor etimologice (de diverse tipuri: fonetice, morfologice sau accentuale), cât și de faptul că unele dintre acestea (la origine variante externe), s-au specializat semantic, devenind cuvinte diferite (vezi, tot dintre exemplele date de el, conferență și conferință, dirigent și diriginte, ibidem, p. 405). La pagina următoare, autorul explică „varietatea formală şi neconsecvenţa sunetelor" cu ajutorul unor dublete sau triplete formale de tipul caracter și haractir, cor și hor, cronică și hronică, cedilă și sedilă, chitară și ghitară, condolență și condoleanță, cifră și țifrăa, ciocolată, şocolată și șocoladă, cuirasă și chirasă, oficer și ofițer etc. În continuare, Pușcariu are în vedere atât concurența în sincronie a variantelor datorate mai multor surse externe, cât și succesiunea lor în diacronie sau în diatopie: „Diferitele forme ale neologismelor se explică mai ales când nu numai limbile din care le-am primit sunt 
diferite, ci și epoca în care au intrat în românește sau provincia în care se întrebuințează" (spre exemplu, cadră și cadru, cler, cliros sau clir, p. 407). Prin toate aceste afirmații și exemple, Sextil Pușcariu anticipează, inclusiv în forme teoretice, conceptul de etimologie multiplă externă, conceptualizat și denumit ulterior, la numai un deceniu diferență, de Alexandru Graur.

Plecând de la exemple de cuvinte extrase din primul volum al DA-ului, vom trece în revistă în continuare câteva situații de reflectare - după opinia noastră - a etimologiei multiple de către redactorii dicționarului academic (în tratarea acestui tip de exemple, nu am citat și conţinuturile, valabile pentru toate variantele, decât atunci când sunt evidențiate tendințe de specializare):

2.1. Referirea la o sursă/limbă complementară (unică sau multiplă) celei principale, în interiorul articolului, cu indicarea variantei /variantelor externe rezultate (în principal de tip fonetic, accentual sau morfologic), dar nu și cu indicarea etimonului/-lor direct/e al/e acesteia/acestora:

- abundanță s.f. [După fr. și: abondanță și, printr-o greșită analogie, abondență, chiar și abundență]. N. din lat. abundantia. [DELR, s.v. abunda: abundénță s.f. (abstr.) 1794 (var. abondánță, Văcărescu, Ist. 126), var. (înv.) abondénță, abundánță < fr. abondance, it. abbondanza, lat. neol. abundantia)];

- administrátor, -toare subst. [După fr., accentuat și: administratór]. - N. din lat. administrator. [DELR, s.v. administra: administrátor s.m. [...] 1787 (Decret or. bis. 7, 9), var. administratór < germ. Administrator ${ }^{\circ}$, lat. neol. administrator, fr. administrateur)]

- advocat s.m. [...] [După fr. și: avocat]. - N. din lat. advocatus. [DELR: AVOCÁT s.m. [...] 1667-1669 (var. avucát, C. Cantacuzino, N. Î. 128v), var.

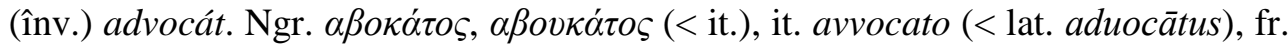
avocat. Var. advocat < lat. neol. aduocatus, germ. Advokat]

- anahoret s.m. [...] [Şi: anacoret. / La scriitorii vechi: anahoritŭ, de-a dreptul din grec.]. - N. din fr. (= grec. $\alpha v \alpha \chi \omega \rho \eta \tau \eta ́ \varsigma)$ [DELR: ANAHORÉT s.m. [...] 1683 (var. anahorít, Dosoftei, V. S. ian. 18), var. anacorét. Lat. neol. anachoreta (< gr. $\dot{\alpha} v \alpha \chi \omega \rho \eta \tau \dot{\zeta}()$, fr. anachorète. Var. anahorí < ngr. $\alpha v \alpha \chi \omega \rho \eta \tau \dot{\zeta} \varsigma]$

- análog (înv.) s.n. (fin.) „taxă ce se impunea fiecăruia și se aduna prin cotizație”. [Cu formă direct grecească, și: análogon s.m. sing. tant, chiar și análogos s.m. sing. tant.] Din ngr. aváioyov [DELR: análog $^{3}$ s.n. (înv.) „taxă ce se impunea fiecăruia şi se aduna prin cotizaţie" 1780 (Prav. Cond. 150), var. análogon,

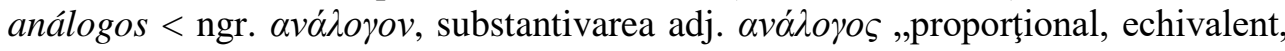
analog"]

- apéndice s.n. ,partea care ține, care atârnă de un lucru (în special de un membru sau de un organ al unei ființe) și care este ca un fel de prelungire a lui”; P. anal. „anexă, supliment, adaos la sfârșitul unei cărți” [Și (după lat., înv.): s.f. și apéndix s.n. Accentuat, mai ales în sensul 1, după fr., și: apendíce] [DELR: APÉNDICE s.n., (înv.) s.f. [...] 1787 (s.f., M. Cantacuzino, G. 233), var. apendíce, apéndix. Lat. neol. appendix, -icem ,ceea ce atârnă de ceva, supliment, accesoriu, apendice”, it. appendice, fr. appendice] 
-- apocalips s.n. [...] [Și: apocalipsă s.f., înv. apocalipsis s.f., direct din grec.] N. din fr. (= lat. apocalypsis < gr. $\dot{\alpha} \pi о \kappa o ́ \lambda v \psi \imath \varsigma)$ [DELR: APOCALÍPSĂ s.f. „,carte din Noul Testament în care este înfățișat în chip alegoric sfârșitul lumii; sfârșitul lumii, (fig.) eveniment catastrofal - apocalypse" 1645 (var. apocalipsis, Varlaam, R. C. $28^{\mathrm{v}}$; var. apocalips, 1678 , Cheia în. $12^{\mathrm{r}}$; forma apocalipsă, 1840 , HeliadeRădulescu, O. ${ }^{3}$ I, 465). Ngr. $\alpha \pi \circ \kappa \alpha ́ \lambda v \psi \imath \varsigma(<$ v. gr. $\dot{\pi} \pi о \kappa \alpha ́ \lambda v \psi \imath \varsigma)$, slavon apokalipsisŭ. Forma apocalípsă, probabil < fr. apocalypse]

- apodoză s.f. (gram.) [Pronunțat, după grec., și: apodosă]. - N. din fr. (grec.

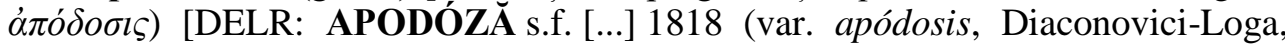

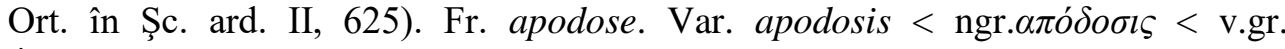
$\dot{\alpha} \pi \delta ́ \delta o \sigma l \varsigma]$

- argúție s.f. (Latinism s. franţuzism) „subtilitate (în argumentare)” [Accentuat, după fr., și: arguție] - N. din lat. argutia, idem [DELR: ARGUȚíE s.f. (livr.) 1840 (Poenaru - Aaron - Hill, V. I, 77), var. argúție. Fr. argutie, împr. din lat. argutiae (pl.). Var. argúție < lat. neol. argutia(e)

- arhetip s.n. [...] [Scris și pronunțat (mai rar, după fr.) și: archetip] - N. din lat. archetypum (< gr. ó $\rho \chi \varepsilon ́ t v \pi o \varsigma)$ [DELR: ARHETíP s.n. [...] 1812 (Şincai, Hr. 399), var. archetíp. Lat. neol. archetypum (< gr.d் $\rho \chi \dot{t} \tau v \pi o v)$, fr. archétype]

- árid, -ă adj. [...] [Accentuat, după fr., și: aríd] [DELR: ARÍD adj. [...] 1859 (Bălășescu, D. R.-Fr.), var. árid. Fr. aride, împr. din lat. aridus. Var. árid < lat. neol. aridus]

- arpégio s.n. [[...] Fără plural. Cu o formă românizată, și: arpegiu. După fr., și arpej]. - N. din it. arpeggio, idem. [DELR: ARPÉGIUs.n. [...] 1840 (Poenaru Aaron - Hill, V. I, 79), var. arpégio, arpéj. It. arpeggio. Var. arpej < fr. arpège $]^{2}$

În unele cazuri, alături de indicarea limbii care explică o variantă, se indică și o alta, pentru altă variantă etimologică, dar cu numirea expresă a etimonului:

- aloe s.f. (bot.) ... [După fr., și alóes s.m. Mai de mult, alóiu s.m., din paleosl. aloŭ.] - Din lat. aloe. [DELR: ALÓE s.f. [...] 1560-1561 (var. alói, Coresi, Tetr. $\left.231^{v}\right)$, var. alóes. Fr. aloès, lat. neol. aloe $(s)<$ gr. $\dot{\lambda} \lambda o ́ \eta$. Var. aloi $<$ slavon aloj $(<$ gr.)]

2.2. Referirea la o sursă complementară celei principale, în interiorul articolului sau la secțiunea de etimologie, cu indicarea variantei externe rezultate, dar și cu indicarea etimonului direct al acesteia, alături de precizarea regiunii în care ea se folosește:

\footnotetext{
2 În aceeași situație se află cuvinte ca album, alcool, alegorie, anagnost, anahoret, anecdotă, antipatie, antrax, apoplexie, arhitect etc. În unele cazuri, forma cuvântului-intrare din DA este astăzi învechită, iar varianta indicată în el ca opțiune a devenit astăzi literară (în acest caz se află, spre exemplu: arbitriu s.n. „voință proprie...” [Prin confuziune cu cuvântul următor (subt influența limbii franceze) și: arbitru. - N. din lat. arbitrium „voință, bun plac” [DELR, s.v. arbitru': arbítru² s.n., în expr. liber ,voință proprie” 1825 (Vârnav, L. 131 v), var. arbitriu < fr. arbitre (împr. din lat. arbitrium); var. arbitriu < lat. neol. arbitrium]. În alte cazuri, situația este mixtă: articol, articul s.n., s.m. [...] Înv., în Transilv., cu pronunțare ungurească, şi: articulúş. - N. din lat. articulus ,articulație, încheietură, aticol”, cu unele accepțiuni nouă, după fr. [DELR: lat. neol. articulus, it. articolo, fr. article. Var. articulúș < magh. artikulus].
} 
- amuletă s.f. [După germ. Amulett, în Trans. și Bucov., și: amulet s.n.]. - N. din fr. ( = lat. amuletum, idem.) [DELR: AMULÉTĂ s.f. [...] c.1832 (var. amulét s.n., I. Golescu, Cond. I, 60'). Fr. amulette (s.f. şi s.m.), împr. din lat. amuletum. Var. amulet, în Trans. şi Buc., < germ. Amulett, lat. neol. amuletum]

- apotecă s.f. (Cuvânt învechit, azi întrebuințat numai la românii din AustroUngaria) „farmacie, spițerie”. După rut. aptika, înv.: aptică ; întrebuințat încă și azi în Bucovina ... sub forma aftică. În Transilv. și Ungaria, după ung. patika, și: potică [...] - Din germ. Apotheke (< lat. apotheca < gr. ó $\pi \circ \theta \dot{\eta} \kappa \eta)$ [DELR:

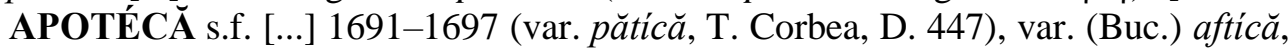
(Trans.) apotícă, (Mold., Buc.) aptícă, (Trans.) potică ${ }^{2}$. Germ Apotheke, lat. neol. apotheca < gr. $\dot{\alpha} \pi o \theta \dot{\eta} \kappa \eta$. Var. aptică < ucr. aptika. Var. potică $\breve{2}^{2}$ magh. patika]

- argumenta vb. [...] [Înv., după germ. argumentieren, derivat prin suf. verb. -ui, și: argumentirui]. - N. după fr. (lat. argumentari, idem) [DELR, s.v. argument: argumentá vb. [...] 1691-1697 (var. argumentuluí T. Corbea, D. 182; forma argumentá, 1829, Poteca, F. 176), var. (înv.) argumentí 1822 (Bobb, DRLU I), argumentiruí 1808 (Țichindeal, A. M. 13), argumentuí 1705 (Cantemir, I. I. 715) < lat. neol. argumentari, fr. argumenter; var. argumentirui < germ. argumentieren]

- armoniza vb. [...] [Învechit și: harmoniza. LB. Înv. armonirui, după germ. harmonieren, prin suf. -ui, obicinuit pe la începutul secol. XIX pentru românizarea neologismelor] - N. din fr.

- arhivă s.f. [...] [Și: arhiv s.n. (formă aproape ieșită din uz, întrebuințată mai ales de românii din Austro-Ungaria, după germ. Archiv)]. - N. după fr. (= lat. archivum) [DELR: ARHÍVĂ s.f. [...] c.1785 (pl. arhíve, Cond. doc. 119 ; forma arhívă, 1786, Beldiman, I. T. 350), var. (înv.) arhív s.n., arhívii (pl.), ar(c)hívum s.n., arșiv s.n., arșivă. Fr.archives. Var. ar(c)hivum < lat. neol. archiuum, archium (pl. archiua).Var. arhiv < germ. Archiv, lat. neol. archiuum. Var. arhivii < it. archivio]

În interiorul acestui caz, sunt de semnalat câteva situații particulare: a) este indicată o variantă externă a intrării, fără niciun fel de informație/sugestie etimologică: afinagiu s.n. (chim.) „operație prin care se purifică o materie” [Și: afinaj]. N. din fr. [Sic!] În această situație, trebuie luată în considerare ipoteza unui etimon dublu: fr. affinage (ptr. var. afinaj) și it. affinaggio (ptr. var. afinagiu), n.n.]; b) sunt indicate două variante etimologice, din care una este raportabilă însă implicit la etimonul indirect, marcat explicit: alimentar, -ă adj. [...] [Și: alimentariu, -ie]. - N. din fr. (lat. alimentarius, -a, -um) [DELR, s.v. aliment: 1856 (Barasch, I. N. II, $184)$ < fr. alimentaire, lat. neol. alimentarius], arbitragiu și arbitraj s.n. [...] - N. din fr. (ital. arbitraggio, idem) [DELR, s.v. arbitrul: arbitráj s.n. [...] 1832 (Heliade-Rădulescu, A. 105), var. (înv.) arbitrágiu < fr. arbitrage [Sic!]; c) nu se indică nicio variantă suplimentară, dar se adaugă un al doilea etimon extern pentru aceeași formă a intrării, cu precizări de ordin diatopic: apocaliptic, -ă adj. [...]. N. din fr. (= gr.). La românii din Austro-Ungaria, după germ. apokalyptisch) [DELR, s.v. apocalipsă: apocalíptic adj. [...] c.1832 (Cornelli, 16 ${ }^{\mathrm{r}}$, apud TDRG $\left.{ }^{3}\right)<$ fr. apocalyptique, germ. apokalyptisch]; d) este indicată o variantă externă, cu 
precizarea etimonului direct și $\mathrm{cu}$ informații diatopice, iar varianta-intrare este explicată, prin „sau”, din două surse externe: arlechin s.m. [...] [La românii din Austro-Ungaria, după germ. Harlekin, și: harlechin] - N. din fr. sau din ital. (arlecchino, idem) [DELR: ARLECHÍN s.m. [...] 1828 (var. arlechén, HeliadeRădulescu, O. II 188), var. (Trans.) harlechín. Fr. arlequin, it. arlecchino. Var. harlechin < germ. Harlequin]; e) varianta-intrare primește un etimon semantic unic, căruia i se indică însă un al doilea etimon care să-i justifice forma: artificiu s.n. [...] - N. după fr. (dar cu forma cuvântului lat. artificium) $)^{3}$.

2.3. sugerarea unei origini multiple a variantelor externe din titlu, în interiorul secțiunii etimologice sau imediat înainte de aceasta: etimonul direct „unic” este urmat în paranteză de etimonul său, interpretabil însă ca etimon direct complementar al uneia dintre variante:

- administratie, administrațiune $=$ administrare. $\mathrm{N}$. din fr. administration (lat. administratio, poate prin intermedierea rus. administracija) [DELR, s.v. administra: administráție s.f. „totalitatea instituțiilor care administrează un stat sau a personalului dintr-o instituție care se ocupă cu administrarea acesteia; administrare" 1722 (Doc. agr. I, 304), var. (înv.) administrațión s.n., administrațiúne < germ. Administration, lat. neol. administratio, -onem, rus. administracija, ulterior întărit și de fr. administration]. În această situație sunt majoritatea cvasiabsolută a dubletelor substantivale în-ie și -iune, dintre care mai amintim accelerație și accelerațiune, admirație și admirațiune, admoniție și admonițiune, adorație și adorațiune, adulație și adulațiune, afectație și afectațiune, afiliație și afiliațiune, afirmație și afirmațiune etc. ${ }^{4}$

2.4. intuirea unei soluții multiple prin explicarea etimonului unic direct (neprecizat) cu ajutorul celui indirect (formulat explicit), însă fără indicarea variantelor externe corespunzătoare:

- afluență s.f. [...] - N. din fr. (= lat. affluentia). [DELR, s.v. afluent: afluénță s.f. [...] 1853 (var. afluință, Wertheimer, Descr. ape. 80) < fr. affluence, lat. neol. affluentia]

- agendá s.f. invar. (com.) „registru sau cărticică ... pentru însemnări”. - N. din fr. (= lat. agenda) [DELR: AGÉNDĂ s.f. [...] 1851 (Stamati, D., 28), var. agénda. Fr. agenda, lat. neol. agenda]

- agonie s.f. [...] [la Cantemir se găsește mai întâi acest neologism, luat de-a dreptul din lat. biser. agona, acuzativul lui agon.] - N. din fr. (= lat. bis. agonia) [DELR: AGONÍE s.f. „stare a organismului care precedă moartea; (p. ext.) suferinţă extremă” 1818 (Budai-Deleanu, O. 718). Fr. agonie, lat. neol. agonia ,angoasă, chin mare; agonie" < gr. $\dot{\alpha} \gamma \omega v i ́ \alpha]$

2.5. referirea, în interiorul secțiunii etimologice, la o unică formă-titlu polisemantică, considerată generic (N.), căreia i se dau mai multe etimoane pentru fiecare dintre sensuri:

\footnotetext{
${ }^{3}$ Despre acest interesant aspect al etimologiei multiple, vezi Bogdan-Oprea 2010, p. 127-171.

${ }^{4}$ Mai rar, apare și situația în care una dintre cele două variante este considerată pe poziție secundă: aluziune s.f. [Și: aluzie]. - N. din fr. (= lat. allusio, -onem).
} 
- afet s.n. [...] - N., în care se recunoaște fr. affùt și germ. La(f)fet(t)e. [DELR: AFÉT s.n. „suport pe care se fixează țeava unui tun” 1789 (M. Strilbițki, apud V. Vascenco, SCL, IX, 1958, 239). Germ. Lafette (< fr. l'affût), rus. lafet (< germ.), cu inițiala după etimonul acestuia, fr. affût „,suport, suport de tun”]

- anticar s.m. 1. (înv.) „adunător, cunoscător și pasionat de antichități”. 2. „negustor de cărți vechi”. În Trans. (după germ.) și anticvar. - N., în sensul 1. după fr. (lat. antiquarius), în sensul 2. după germ. Antiquar. [DELR, s.v. antic adj.: anticár $^{2}$ s.m. „vânzător sau colecţionar de cărţi şi alte obiecte vechi; (înv.) cercetător al lucrurilor vechi, al obiectelor antice; (înv., adj.) care ţine de studiul obiectelor antice, arheologic" 1830 (CR, 60 bis), var. (înv.) anticáriu, anticuár, (înv., Trans.) anticvár < fr. antiquaire, germ. Antiquar, lat. neol. antiquarius „cunoscător sau iubitor de antichităţi”]

2.6. indicarea implicită a unei etimologii multiple (mixte) prin calc lexical (de structură semantică), lexico-gramatical sau frazeologic ${ }^{5}$ :

- ac s.n. [...] II. (Tehn.) O porțiune de șine mobile, care mijlocește mutarea trenului de pe o linie pe alta, macaz. - E lat. acus, -us, care, trecând la decl. II, a devenit masculin, ca și ital. ago [...]. În sfârșit $a c$ II e traducerea românească a fr. aiguilles. [DELR: AC [ar., mr.; ir.åc] s.n. „mică ustensilă subțire de metal, prevăzută cu un orificiu prin care se trece un fir, folosită la cusut; numele altor piese de această formă; frunză îngustă, ascuțită, caracteristică coniferelor; organ de apărare și de atac al unor animale, în formă de ghimpe sau de vârf ascuțit; macaz" 1508 (DERS). Lat. acus, cf. dalm., it., sd. REW 130. Sensul „macaz”, după fr. aiguille [de chemin de fer], germ. Nadel.

- aer s.n. I. [...]. II. După franțuzește, găsim de timpuriu și sensul de ,înfățișare, aspect, expresie, fizionomie". III. (înv.) După fr. a încercat C. Negruzzi să introducă pe aer și cu sensul de ,arie, cântare". [În sensul I aer nu are plural]. Din lat. aer, aerem. [DELR: ÁER ${ }^{1}$ [ar. áir; ir. åier] s.n. ,,amestec de gaze care alcătuiesc straturile inferioare ale atmosferei și care este absolut necesar vieții; înfățișare, aspect, atitudine; (înv.) arie muzicală" 1581 (Coresi, Ev. 357). Lat. āēe, āerem (< gr. $\dot{\alpha} \eta \dot{\rho}, \dot{\alpha} \varepsilon \dot{\varepsilon} \rho o \varsigma$ ), cf. v.it., ret., fr., occ., sp., cat., ptg. REW 240, cu sensul „,̂nfățișare, aspect, atitudine” după fr. $\operatorname{air}(s)$. Sensul, ,arie muzicală”, calc după fr. air, it. aria.

- alb, -ă adj., subst. [...] 3. (după fr.) armă albă = armă de oțel ,arme blanche”; (după fr.) noapte albă „nuit blanche” [DELR: ALB [ar. álbu; mr.; ir. åb] adj., s.n., s.m. „care are culoarea zăpezii, a laptelui; culoarea albă; persoană aparţinând rasei albe; (ist.) conservator" 1389 (antrop. Albul, DERS). Lat. albus, panrom. REW 331. Sensul „,conservator”, după fr. blanc. În expresii neologice (armă albă, carne albă, noapte albă), după fr. blanc, blanche]

- aplecare s.f. I. [...]. II. La scriitorii moderni, cu sensul de ,înclinare, predispoziție” (ca traducere a fran. ,inclination, penchant” sau a germ. „Neigung”.

\footnotetext{
${ }^{5}$ Calcurile lexicale de structură morfematică sunt notate, de regulă, prin indicarea modelului extern (vezi, spre exemplu: afacere s.f. [...] - N. după fr., afemeiat, -ă adj. [...] - N. după fr. efféminé etc.). În mai puține cazuri, cuvântului calchiat i se dau, în mod explicit, două modele externe: ante-braț s.n. [...] - Compus din lat. ante „înainte” și braț (după fr. avantbras sau ital. antibraccio).
} 
- arbore s.m. [...]. Spec. (Bot.) Arborele-vieții: ,arbre de vie”, [...]; arbore genealogic: „arbre généalogique”; [...] arbore enciclopedic: ,arbre encyclopédique”; 2. (Mar. Franțuzism) „,catarg”; 3. (Mecan. Franțuzism) fusul cel mare, la o mașină, axa ... care servește la transmiterea mișcării”. - Din lat. arbor, -orem. În întrebuințările de sub II, e neologism. [ DELR: ÁRBORE s.m. „plantă cu trunchiul lemnos, înalt și ramificat, copac; catarg; organ de mașină care primește și transmite o mișcare prin rotaţia în jurul axei sale" 1471 (antrop. Arbure, DERS; ca apelativ, 1551-1553, var. árbure, Ev. sl.-rom. 45 ), var. árbor, (hapax, PO, 211, la pl.) árbuni, (reg., înv.) hárbur. Lat. arbor, -em, cf. dalm., it., friul., fr., occ., cat., sp., ptg. REW 606. Cu sensurile „,catarg” și „,axul unui mecanism”, după fr. arbre]

- arătător s.n. (În Transilv., după germ. „Uhr-(zeiger”) „limba ceasornicului (a busolei etc.)". Derivat din arăta, prin suf. instr. -ător [DELR, s.v. arăta: arătătór adj., s.n. „degetul al doilea de la mână (cu care se arată); (înv.) care arată; (înv., Trans.) limbă de ceas; (înv., gram.) (modul) indicativ, (pronume) demonstrativ; (înv., mat.) exponent” 1581 (Coresi, Ev. 198), cu sensul „limbă de ceas” după germ. (Uhr)zeiger, cu sensul ,indicativ” după lat. indicatiuus, cu sensul ,demonstrativ" după lat. demonstratiuus]. În acest din urmă exemplu, derivatul adjectival este vechi și popular, în vreme ce transformarea lui în substantiv se datorează unor modele neologice, în funcție de sensuri, ceea ce înseamnă că este vorba despre un calc lexico-gramatical.

- armă s.f. [...] În limba literară de azi, cuvântul armă a primit, mai ales subt influența limbii franceze, unele sensuri nouă și specificări ale înțelesului: „fel sau categorie de armată”, (la pl.) „meseria de soldat” etc. Din lat. arma.

2.7. indicarea prin sau, în interiorul secțiunii etimologice, cu referire la o singură formă-titlu, a două surse externe diferite (fără menționarea vreunei variante secundare, cu sau fără precizarea originii comune a celor două surse înrudite):

- acaț s.m. (Bot.) = salcâm. Din ung. akác sau germ. Akazie, împrumutate din lat. acacia. [DELR, s.v. acacia: acáț s.m. (Trans.) ,salcâm” 1783 (Benkö 28), var. acáțăn, acáțies.f. 1857 (Polizu, V.), acáțiu, arcáț < magh. akác < germ. Akazie „acacia; (pop.) salcâm”; var. acáție < germ. Akazie; var. acáțăn $\leftarrow$ acaț, infl. de frasăn, mesteacăn; var. arcáț $\leftarrow a c a t ̦$, infl. de arțar]

- apriori loc. adj., loc. adv. [...] - N. din fr. sau din germ. (= lat. scolastică $a$ priori ,după (sau din) ceea ce este înainte”)

- aprioritate s.f. (filos.) - N. după fr. sau germ. (Apriorität) [MDA s.v.: fr. apriorité, germ. Apriorität $]^{6}$

2.8. Situații în care se fac comentarii personalizate, cu sau fără citarea explicită a etimoanelor variantelor, cu sau fără indicarea explicită a unei surse multiple:

\footnotetext{
${ }^{6}$ Un caz particular de etimologie multiplă exprimată prin „sau” este explicaţia etimologică a lui arendaş s.m. [...]. - Derivat din arendă, prin suf. nom. agent. -aș, sau luat de-a dreptul din ung. árendás. [DELR, s.v. arendă: arendáș s.m. [...] 1772 (Iorga, S. D. XII, 186), var. (înv., Mold.) orândáş̧ $\leftarrow$ arendă sau < magh. árendás]. La fel, vezi explicația pentru arhivar s.m. - Derivat din arhivă, prin suf. nom. agent. -ar (sau din germ. Archivar).
} 
- aghiasmă s.f. „apă sfințită; (ironic) rachiu” [Și: aghiazmă; cu pronunțare grecească: aiasmă, aiazmă; în Banat și: iasmă]. - Din medio-grec. $\dot{\alpha} \gamma i \alpha \sigma \mu \alpha$, paleosl. agiazma. [DELR: AGHEÁSMẲ s.f. (în religia creștină),,apă sfințită” 1656 (var. aghiázmă, Scutul cat. ${ }^{2} 16$ ), var. aiásmă, aiázmăa, (Ban.) iásmă $\breve{1}^{1}$ Slavon agiazma (< gr. $\dot{\alpha} \gamma i \alpha \sigma \mu \alpha)$. Var. aiazmă, iasmă < bg. (a)jazma, ngr. aji $\alpha \sigma \mu \alpha]$

- anason s.m. (bot.) [...] [Plantei i se mai zice, după lat., anis; după grec. óvloov: anison; în Trans., după ung. anis: aniş; în Mold., anos, hanos.] Din tc. anason. [DELR: ANASÓN s.m. [...] 1696-1697 (Anatef. 95), var. (Mold., E Trans.) alisión, alisón, anesón, anisón. Tc. anason, anısun (< arab anīsūn < gr.). Var. anison (alision, alison, aneson) < ngr. $\dot{\alpha} v l \sigma o v<$ v.gr. $\ddot{\alpha} v \eta \sigma o v, \ddot{\alpha} v \eta \theta o v$,mărar; anason”]

- anátemă s.f., adj. invar. [Scris în vechime cu tetha; pronunțat și anátima și, după obiceiul slav, și: anáfema, anáftima, anáftema. Astăzi, la clasele culte, se găsește, după fr., și accentuarea: anatémă]. Din m.-grec. $\alpha v \alpha ́ \theta \varepsilon \mu \alpha$, introdus în limbă prin scrierile bisericești, deci, în cea mai mare parte, prin mijlocire slavă: paleosl. anathema, anafema. [DELR: ANATÉMĂ s.f. [...] 1560-1561 (var. anátema, Coresi, Pravila, $\left.4^{\vee}\right)$, var. anáf(t)emă, anátemă, anátima, (Olt.) nátemă, nátimă. Slavon anatema, anaf(t)ema, anathema, ngr. $\alpha v \alpha \dot{\theta} \theta \mu \alpha$. Var. nátemă $<$ bg. dial. natema. Accentuarea anatémă, după fr. anathème]

- anticrist s.m. [...] Forma anticrist este neologică; cea veche, antihrist, e

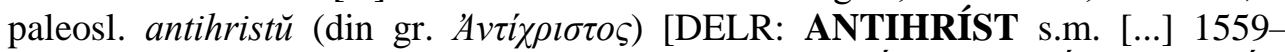
1560 (Cod. Bratul, 324, 334), var. anticríst, (reg.) antehấrs(t), antihấrs(t), antihấrţ.

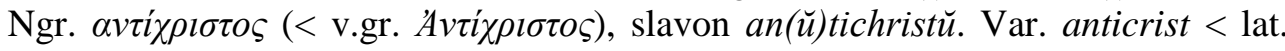
neol. antichristus]

- apotecar s.m. [...]. [Și: apoticar, poticar. Înv. și dial.: apotecariu] - La cronicari, era neologism din lat.-med. apothecarius (cf. fr. apothicaire, rus. aptekarı̆, pol. aptekarz, ung. patikarius, germ. Apotheker); iar azi, la românii din AustroUngaria, e românizarea germ. Apotheker „farmacist” [DELR, s.v. apotecă: apotecár s.m. (Buc., Trans.) „farmacist” 1648 (Năsturel, Varlaam - Ioasaf, 220v), var. (Trans.) apoticár, păticár, poticár < lat. neol. apothecarius, eventual și rus. ap (o)tekar', ulterior şi $\leftarrow$ apotecă , după germ. Apotheker]

- apostat adj., s.m. [...] [La Dosoftei, V.S. 127/2 și: apostata s.m.] - N., la scriitorii mai vechi din lat. apostata sau direct din grec. $\dot{\pi} \pi 0 \sigma \tau \dot{\alpha} \tau \eta \varsigma$, la cei mai noi din fr. [DELR: APOSTÁT adj., s.m. [...] 1682 (Dosoftei, V. S. oct. 93), var. (înv.) apóstata. Ngr. $\alpha \pi 0 \sigma \tau \dot{\alpha} \tau \eta \varsigma$ (< v.gr. $\dot{\alpha} \pi o \sigma \tau \dot{\alpha} \tau \eta \varsigma)$, fr. apostat. Var. apostata < lat. neol. apostata]

- arendă s.f. [...] - În România cuvântul a pătruns, pe la începutul veacului trecut, prin ruși: arenda; în Transilv. îl găsim ceva mai de timpuriu şi e luat de la unguri: árenda. Se găsește și la sârbi, bulgari și poloni (arenda), unde, ca și la noi, a devenit popular, relativ de curând, fiind introdus din apus (lat.-med. arenda [...], dimpreună cu instituțiunea ,,arendării”

[DELR: ARÉNDĂ s.f. [...] 1737 (Doc. agr. I, 368), var. (Trans., Buc.) arấndă, aríndă, (înv. Mold.) orấndă, oréndă, oríndă. Magh. árenda $(<$ lat. med. arenda), pol. arenda (în Mold.), rus. arenda (în Mold. și Munt.).] 


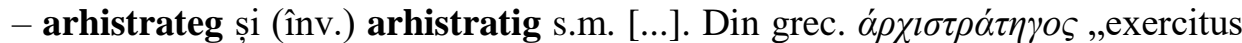
imperator". Cuvântul a intrat în trei epoce diferite în limba română: 1. În limba veche, prin scrierile bisericești, din limba medio-greacă (sau din cea paleoslavă: arhistratigŭ), cu sensul fig. de „mai marele cetelor îngerești” [...]; 2. În epoca fanarioților, din limba neo-grecească, cu sensul propriu de ,general comandant al unei armate". 3. Ca neologism, în timpurile recente, sub forma arhistrateg, după fr.

- armistiție și armistițiu s.n. [...] - N., la scriitorii noi, după fr.; la cei vechi, din lat.-med. armistitium [...], poate prin filiațiune polonă: armistycyum. [DELR: ARMISTÍŢIU s.n. [...] 1699 (var. armistițies.f., FN, 85), var. (înv.) armistiți, armistrítie s.f., armistrițiu. Lat. neol. armistitium, it. armistizio, fr. armistice]

- armonie s.f. [...] [Scris și rostit, din ce în ce mai rar, și: harmonie.] - N., la scriitorii vechi (Dosoftei) din grec. $\dot{\rho} \mu$ ovía [...] sau din lat. harmonia (Cantemir); la scriitorii mai noi, din fr. sau din ital. armonia, idem. [DELR: ARMONÍE ${ }^{\mathbf{1}}$ s.f.

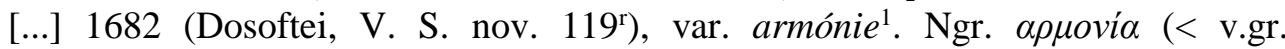
$\dot{\alpha} \rho \mu o v i \alpha)$, lat. neol. harmonia, it. armonia, fr. harmonie].

2.9. indicarea, pentru aceeași formă-intrare, a două etimoane externe, cu sau fără menționarea vreunui argument de ordin lingvistic:

- arhimandrit s.m. [...]. - Din paleosl. arhimandritǔ, n.-grec. $\alpha \rho \chi \mu \alpha \alpha \delta \rho i \tau \eta \varsigma$, idem. [DELR: ARHIMANDRÍT s.m. [...] 1643 (Varlaam, Caz. 352). Slavon arhimandritǔ, ngr. $\alpha \rho \chi \imath \mu \alpha v \delta \rho i \tau t \eta \varsigma]$

- arhanghel s.m. [Scris în vechime, după felul greco-slav, și: arhaggel, azi și: archanghel. În veacul trecut se găsesc și formele latinizate: arhangel și arcangel [...] - Cuvânt intrat în grai prin biserică: paleosl. arhangelŭ, gr. ’́ $\rho \chi \alpha ́ \gamma \gamma \varepsilon \lambda o \varsigma]$ [DELR: ARHÁNGHELs.m. [...] 1535 (top., DRH B III, 36; ca apelativ, 1566, Coresi, L. 210), var. (Ban.) aránghel, (Mold.) arcángel, h(a)ránghel. Slavon archangelŭ, ngr., gr. neol. $\dot{\alpha} \rho \chi \dot{\alpha} \gamma \gamma \varepsilon \lambda \circ \varsigma]$

- armie s.f. [...] - Împrumutat din pol. armia (la Costin) și din rus. armija (pe timpul ocupației rusești) [DELR, s.v. armă: ármie s.f. [...] 1712 (N. Costin, în Let. II, 67) < pol. armja (< germ. Armee < fr. armée), rus. armija (< germ. Armee sau fr. armée)]

\section{Comentarii și concluzii}

În destul de multe cazuri, nu este precizată și nici sugerată o etimologie multiplă, chiar dacă prezența explicită a variantelor etimologice confirmă o dublă sau triplă proveniență (în general este vorba despre neologisme, cărora autorii nu le acordau o importanță similară cu cea referitoare la cuvintele moștenite sau la împrumuturile mai vechi): algébră s.f. [...] [Accentuat și: álgebră]. - N. din fr. (= lat.-med. algebra, din arab. al-dzebr) [DELR: ALGÉBRĂ s.f. 1793 (var. alghevră, Gherasim, V. H. 9v; forma algebră, 1837, Asachi, E. II), var. (înv.) álgebră, alghébră (1818, Asachi, Alghebra). Fr. algèbre (< lat. med. algebra $<$ arab al art. hot. + jabr). Var. alghebră < lat. neol. algebra, germ. Algebra. Var. álgebră < lat. neol. algebra. Var. alghevră < ngr. $\alpha \dot{\lambda} \gamma \varepsilon \beta \rho \alpha$ ], aligatór s.m. [...] [Accentuat și: aligátor]. - N. din fr. [DELR: ALIGATÓR s.m. [...] 1806 (var. aligátor, Şincai, I. 
nat. 71). Fr. alligator (< engl. alligator < sp. el lagarto „caimanul”, propriu-zis "sopârla" < lat. *lacartus = lacertus). Var. aligátor < germ. Alligator] etc.

Din parcurgerea exemplelor este evidentă conștiința faptului că un cuvânt poate proveni din două sau mai multe surse externe, teoretizată, de altfel, în 1940 de însuși Sextil Pușcariu (vezi supra).

Tratamentul acestor situații în Dicționarul academic este relativ lipsit de omogenitate, dat fiind numărul mare al variaţiilor de redactare, ceea ce arată efortul fiecărui autor de a se apropia cât mai mult de ceea ce considera că este soluția cea mai adecvată.

În destul de multe cazuri, autorii optează spre o unică soluție: act s.n. [...] - N. din fr. [DELR: Fr. acte, lat. neol. actum „faptă” (pl. acta ,acțiunile unei autorităţi”, de unde ,document oficial”), actus ,acțiune, act al unei piese de teatru”]; afabil, -ă adj. [...] - N. din fr. [DELR: AFÁBIL adj. [...] c.1832 (I. Golescu, Cond. I, 119'). Fr. affable, lat. neol. affabilis]

DA-ul rămâne, prin diversitatea abordării unor cazuri similare, un exemplu de tratare lexicografică personalizată, fapt care presupune un mare grad de responsabilizare, pe de o parte, și care demonstrează cultura lingvistică a autorilor, pe de altă parte. Tot Sextil Pușcariu, în articolul numit În jurul Dicționarului limbii române (I) din 1908, spunea:

„Pe cât e însă de îmbucurător că în ştiință a dispărut aproapte cu desăvârşire diletantismul ..., pe atât e de nefirească răceala interesului general față de cestiuni de limbă. [...] Interesul pentru limbă izvorăște dintr-un simț firesc, precum dorința de a asculta o cântare, de a ceti o poezie sau de a rătăci prin potecile unei grădini înflorite [...]"”

Patronajul lui Sextil Pușcariu asupra variantei finale și asupra activității colaboratorilor săi arată, inclusiv prin evidențierea situațiilor de mai sus, încredere, viziune și înțelepciune, dar și o mare dragoste pentru limba română.

În studiul care precedă volumul I al DA, Pușcariu anticipează, sui generis, principiul etimologiei multiple astfel: „În cele mai multe cazuri e cu neputinţă a distinge dacă neologismul e un împrumut din latinește sau din franţuzește, căci de obicei ne-au slujit de model amândouă limbile acestea".

\section{ABREVIERI BIBLIOGRAFICE. SIGLE}

ALIL = „Anuar de lingvistică şi istorie literară”, Academia Română, Filiala Iaşi, Institutul de Filologie Română „A. Philippide” din Iași (http://alil.academiaromana-is.ro/)

Bogdan-Oprea 2010 = Helga Bogdan-Oprea, Un tip special de etimologie multiplă: neologisme româneşti care se explică formal prin latină şi semantic prin franceză, în Lupu (ed.) 2010, p. 127-171.

Bogdan-Oprea 2011 = Helga Bogdan-Oprea, Relatinizarea limbii române. Privire generală: accepții, delimitări, aspecte, București, Editura Universitătii din București.

Celac-Moroianu 2018 = Victor Celac și Cristian Moroianu, Etimologie, în Marius Sala şi Nicolae Saramandu (ed.), Lingvistică românească, București, Editura Academiei Române, p. 291-322.

\footnotetext{
${ }^{7}$ Apărut pentru prima dată în „Convorbiri literare”, XLII, nr. 3, martie, p. 321-330, republicat în Pușcariu 1974, p. 14-19.
} 
Celac 2017 = Victor Celac, Etimologia multiplă în limba română: cadru metodologic și criterii, în ALIL, t. LVII, 2017, Bucureşti, p. 101-130.

DA = Dicţionarul limbii române. Sub conducerea lui Sextil Puşcariu. Tomul I, partea I: $A-B$, București, Librăriile Socec \& Co. şi C. Sfetea, 1913 (apărut pe fascicule în 1906-1912);

DELR = Dicționarul etimologic al limbii române (ediție revăzută și adăugită). Vol. I (litera $A$ ), coordonatori: Ion Giurgea și Cristian Moroianu (varianta online: https://delr.solirom.ro/)

Lupu (ed.) 2010 = Coman Lupu (ed.), Las lenguas románicas y la neología, Bucureşti, Editura Universităţii din Bucureşti.

MDA = Micul dicționar academic, Academia Română, Institutul de Lingvistică „Iorgu Iordan - Al. Rosetti”, vol. I (literele $A-M e$ ), București, Univers Enciclopedic Gold, 2010.

Pușcariu 1940 = Sextil Pușcariu, Limba română. Vol. I. Privire generală, București, Fundaţia pentru Literatură şi Artă „Regele Carol II”.

Pușcariu 1974 = Sextil Pușcariu, Cercetări și studii. Ediție îngrijită de Ilie Dan, prefață de G. Istrate, București, Editura Minerva.

\section{THE CASE OF MULTIPLE ETYMOLOGY IN THE ACADEMIC DICTIONARY OF THE ROMANIAN LANGUAGE (DA) \\ (Abstract)}

The present article discusses the way in which the authors of the Academic Dictionary of the Romanian Language (hence DA), beginning with Sextil Pușcariu, marked the cases of external multiple etymology a couple of decades before Alexandru Graur introduced the concept in Romanian linguistics. Having worked assiduously to the DA, and being a fine observer and theoretician of language evolution, Sextil Pușcariu foresaw the phenomenon and thus the concept of multiple etymology in his landmark book (1940), The Romanian Language. I. A General Overview.

Cuvinte-cheie: etimologie multiplă, origine directă, variante etimologice, vecinătăți lexicale, calc lingvistic.

Keywords: multiple etymology, direct origin, etymological variants, lexical borrowing, linguistic calque.

Institutul de Lingvistică ,Iorgu Iordan - Al. Rosetti” al Academiei Române

București, Calea 13 Septembrie, 13

cristian.moroianu@litere.unibuc.ro 